\title{
Research
}

\section{Does Integrated Water Resources Management Support Institutional Change? The Case of Water Policy Reform in Israel}

\author{
$\underline{\text { Itay Fischhendler }}^{1}$ and Tanya Heikkila ${ }^{2}$
}

\begin{abstract}
Many international efforts have been made to encourage integrated water resources management through recommendations from both the academic and the aid and development sectors. Recently, it has been argued that integrated water resources management can help foster better adaptation of management and policy responses to emerging water crises. Nevertheless, few empirical studies have assessed how this type of management works in practice and what an integrated water management system implies for institutional adaptation and change. Our assessment of the Israeli water sector provides one view of how they can be shaped by an integrated structure in the water sector. Our analysis of recent efforts to adapt Israel's water management system to new conditions and uncertainties reveals that the interconnectedness of the system and the consensus decision-making process, led by a dominant actor who coordinates and sets the policy agenda, tends to increase the complexity of negotiations. In addition, the physical integration of water management leads to sunk costs of large-scale physical infrastructure. Both these factors create a path dependency that empowers players who receive benefits from maintaining the existing system. This impedes institutional reform of the water management system and suggests that integrated water resources management creates policy and management continuity that may only be amenable to incremental changes. In contrast, real adaptation that requires reversibility and the ability to change management strategies in response to new information or monitoring of specific management outcomes.
\end{abstract}

Key Words: integrated water resources management; institutional change and adaptation; water policy; Israel

\section{INTRODUCTION}

Worldwide, efforts to reform water resource management and governance institutions have gotten under way in recent decades. Some of these reforms focus on the devolution of decision-making authority from national or federal governments to local governments, river basin organizations, and local water users (Kemper et al. 2007). Often included among these recent reform efforts is integrated water resources management (IWRM). IWRM is intended to bring together fragmented water institutions and users into an integrated planning, allocation, and management framework, often at the scale of an entire watershed (GWP 2000).

Although IWRM is widely seen as a beneficial and sustainable water management approach (e.g., see
Ohlson 1999, Newson 2000, Matondo 2002), some scholars have taken more critical views of IWRM (e.g., see Biswas 2004, Blomquist and Schlager 2005). Because much of the IWRM literature remains theoretical and prescriptive, it is unclear in what ways the benefits or limitations of IWRM play out in practice (Medema and Jeffrey 2005). An important question that has been raised recently is how the features of IWRM foster the capacity of governance institutions to change and adapt over time.

In this paper, we discuss how IWRM, which was established in Israel more than 50 years ago, has influenced water policy and institutional change in Israel over time. In doing so, we highlight how the integrated structure of the Israeli water sector prior to reform created an impediment to smooth adaptation and change. Through an in-depth case 
study of the Israeli water reform process, we contribute to the debate over the benefits and limitations of IWRM by looking at what IWRM implies for institutional change.

\section{FEATURES, BENEFITS, AND CHALLENGES OF INTEGRATED WATER RESOURCES MANAGEMENT}

\section{Features}

Although myriad definitions of IWRM exist in the literature (Biswas 2004, Medema and Jeffrey 2005), a few key features of IWRM are consistently recognized. First, much of the literature agrees that the "integrated" component of IWRM involves physical, sectoral, and organizational integration (Kidd and Shaw 2007). Physical integration implies coordination at the basin level or catchment scale of a water body. It aims to integrate the management and use of all the elements of the natural hydrologic system, including surface water, groundwater, riparian lands, and floodplains or wetlands. Sectoral integration requires coordination across different types of water users such as energy, municipal supply, agriculture, and ecology. This implies that specific management choices need to be coordinated, such as reservoir releases, regulatory decisions on water quality, infrastructure planning, watershed protection, and water pricing. Organizational integration can then help facilitate physical and sectoral integration by bringing together the government units, agencies, water user associations, and private organizations that have responsibilities for managing different sectoral users or physical infrastructure.

To achieve physical, sectoral, and organizational integration under IWRM, institutional arrangements, including public agencies, laws, or management agreements, may need to be established to provide formal coordination in decision making around water allocation and management (Bressers and Kuks 2004). Institutional integration also is likely to require substantial financial resources dedicated to coordination among organizations and sectors. Opportunities for water users and other interested stakeholders to participate in the institutions for planning and other management decisions are also seen as essential to IWRM (GWP 2004).

\section{Benefits}

The literature has also identified potential benefits of IWRM. One of the purported benefits is that management decisions among resources or users of water supplies theoretically can be made more efficiently and effectively (Teclaff 1996, Blatter and Ingram 2000, Molle et al. 2006). Another oftencited benefit of IWRM is that it brings diverse stakeholders into decision-making processes, which can create more equitable water management choices (UNEP 2006, GWP 2007) and prevent conflicts (Dublin Statement 1992, Asian Development Bank 2006).

In theory, the integration of more stakeholders from different sectors and management institutions into a single management approach can also provide a platform for water users to adapt and respond collectively to the detrimental implications of uncertainties over water management or unforeseen conditions such as droughts or floods (e.g., see UNEP 2006, Pahl-Wostl 2007, Watson 2007, Mitchell 2007; UN Water, unpublished document). Settings that involve multistakeholder participation are supposed to elicit diverse forms of knowledge and information about competing demands and the potential interactions and trade-offs among these demands and, in theory, provide an informed platform through which decision makers can more effectively learn from one another and adapt to changing circumstances (Brunner and Steelman 2005).

Providing more resiliencies against environmental uncertainties is considered crucial given the effects of climate change on water resource availability as well as temporal and spatial variability in water supplies. Taken to its next step, some then argue that IWRM not only facilitates adaptation but could be combined with "adaptive management" as a water management approach (Jeffrey and Geary 2006, Timmerman et al. 2008). Medema and Jeffrey (2005) have undertaken a thorough analysis of the theoretical opportunities to blend IWRM with adaptive management approaches and, although they recognize that these concepts complement one another, they warn that IWRM may struggle with the institutional flexibility that is typically needed for more "adaptive" approaches to water resource management. 


\section{Challenges to institutional change}

Medema and Jeffrey's (2005) assessment of the compatibility between IWRM and adaptive management, which focuses on the operational level or day-to-day adaptability features that water managers face, raises a broader question: What effect do IWRM systems have on the capacity of systems to engage in larger-scale policy and institutional reforms for governing the water sector? As noted, many attempts to implement IWRM have failed (Jonker 2002, Jeffery and Geary 2006, PahlWostl and Jeffrey 2007). Even in cases in which IWRM has been implemented, it does not always deliver its expected outcome (Shah and van Koppen 2006). If this is the case, does the IWRM "process" foster the institutional changes needed to improve the system?

Although little empirical evidence currently exists to answer this question, some of the literature on IWRM and institutional change, specifically in the water sector, provides insights. First, with sectoral and organizational integration, scholars have recognized that there are likely to be substantial collective-action challenges in getting diverse water users across entire watersheds to agree on new policies and institutional structures (Blomquist and Schlager 2005). This is largely because multiple and diverse actors increase the transaction costs, i.e., the costs of negotiating, bargaining, and searching for solutions, which are known to impede institutional change (Williamson 1981, North 1990, Ostrom 1990, Taylor and Singleton 1993).

Moreover, as Biswas (2004) notes, the problem of institutional change becomes substantially more complex because under an IWRM approach it is not just the water sector that is involved in the political and management choices. The agricultural, environmental, industrial, and energy sectors are all players in an IWRM process, which "becomes difficult to achieve because of extensive turf wars, bureaucratic infighting, and legal regimes" (Biswas 2004:254). What this implies is that not only will institutional reforms be challenging because of the diversity of interests that must come to agreement, but that entrenched interests may fight change to avoid altering their historic preferences or benefits for water allocation, a point that has been well taken by scholars of institutional and policy change (Baumgartner and Jones 1993, Sabatier and Jenkins-Smith 1993, Stone 2002).
A second potential challenge presented by IWRM stems from the physical integration of an IWRM system. As others have noted, the scale and dimensionality of a physical landscape can have important implications for adaptive capacity (Van Cleve et al. 2006). Expansive scales and multiple physical dimensions can make it difficult for stakeholders to agree on what to adapt and how, or create high "sunk costs," i.e., costs that cannot be recovered, that may impede their willingness to alter these systems (Ingram and Fraser 2006). Even if institutional changes could be achieved without major infrastructure alterations, many water supply systems and allocation regimes have been developed to ensure high reliability of resource flows, which can also impede the likelihood that resource users will be open to change (Roe and Van Eeten 2002). As institutional theorists widely recognize, the relative benefits of such institutional arrangements can therefore tend to increase over time, which in turn increases the costs of institutional change (Levy 1997, Pierson 2000).

\section{ADAPTING THE ISRAELI INTEGRATED SYSTEM}

In light of the fact that the literature has provided only limited theoretical and empirical guidance to explain whether or how IWRM supports or hinders institutional change, we argue that a case study of institutional change within an IWRM setting provides valuable lessons for extending the theory and developing testable propositions for future research. The case study of Israel's recent water sector reform provides background evidence of how Israel's IWRM system developed. Then it discusses why and when reforms were proposed and how the reform process worked. The data for this case study come from reviewing correspondence between Israeli water officials, personal interviews with Israeli policy makers, and reviews of primary legal documents and committee reports, as well as secondary sources such as historical studies and current literature on the Israeli water setting.

\section{The history of Israel's integrated water resources management system}

In Israel, water was never regarded as a mere economic resource but as a building block in the creation of a new society in the land of Israel (Galnoor 1978) and as a source of legitimacy for the 
construction of the state (Alatout 2007). This society was based on several Zionist ideologies. The first ideological factor specifically stipulated settlement of the Negev desert, with little regard for the economic costs. This ideology was supported by the second ideology of spatial equality under which all areas within the state would receive water of the same quality and at the same price. To this end, an equalization fund was established to cross-subsidize water users in mountainous areas and the south (Hochman and Hochman 1991). This created spatial equality under which all areas within the state receive water of the same quality and at the same price, regardless of its true cost (Kislev 2006). The third ideological factor called for the building of an agrarian society. This ideology gave precedence to the agricultural sector (E. Feitelson and J. A. Allan, unpublished manuscript) by subsidizing the price of water and incomes for the agricultural sector. The fourth factor was the ideology of "statism," which placed the state at the center of decision-making authority. It required the development of both the water and the agricultural sectors in a centrally organized and cohesive manner (Aharoni 1991:146-148).

To further implement the Zionist-agricultural ideology, Israel also embarked on a large-scale effort to harness the nation's available water through extensive water storage and delivery systems (Galnoor 1978). As part of this vast hydraulic mission, the National Water Carrier was built to connect all three major water resources, namely, the Sea of Galilee in the north, the Mountain Aquifer in the east, and the Coastal Aquifer, into one integrated system. As a result, the nation's one lake and its major aquifers were interconnected, establishing a single system that facilitates conjunctive water management and use, as shown in Fig. 1. Finally, in the last two decades tremendous efforts have been made to integrate water and wastewater systems for the reuse of treated wastewater for agriculture.

Institutional integration of the water sector also began as early as 1959, when Israel enacted its Water Law with the aim of providing Israel's national government complete control over the resource. The law was amended in 1972 to integrate quality and quantity under one policy while also establishing some government authority over land use in the vicinity of water resources. This law set the basis for the establishment of an institutional structure that would regulate, price, and distribute water, thereby achieving both sectoral and institutional integration.

The physical, sectoral, and institutional integration of the water sector was facilitated organizationally through the establishment of the Israeli Water Commission, which was appointed by the government. The Water Commission was tasked with approving all water appropriations and allocations. At the same time, the government aimed to coordinate the activities of eight different government ministries with water-related authorities through the Water Commission to foster a nationally integrated water policy (IPEWA 2005g). Nevertheless, the Water Commission's policies were dominated by the Ministry of Agriculture in an effort to fulfill the agrarian ideological goals mentioned above (Alatout 2008). In addition, the water commissioners were appointed by the recommendations of the Minister of Agriculture; thus all commissioners until the 1990s were from agrarian backgrounds (Feitelson et al. 2007).

The Zionist ideologies and implementation tools, while stressing the physical integration of the system, also excluded other elements of IWRM necessary for balancing diverse interests. These include institutional mechanisms for public participation and representation of the environmental and tourism interests, concerns that were not part of the political discourse when the system was established half a century ago. Some also argue that this was a result of the attempt of the Zionist leaders to construct an uncontested mandate about how and who should own and manage the resource (Alatout 2008). The only exception in this case is the establishment of a Water Council in the late 1950s as an oversight institution. However, it did not ensure the participation of stakeholders in the decision making process because it had only advisory power and the majority of its members were from the agricultural sector.

Another limitation of the Israeli IWRM system is that it neglected many of the elements of economic efficiency and managing demand through economic instruments such as water markets and full-cost recovery. Such mechanisms were often rejected by the agricultural lobby that has dominated the parliamentarian subcommittee responsible for approving new water tariffs (Feitelson 2005). 
Fig. 1. The Israeli water conveyance system and water resources.

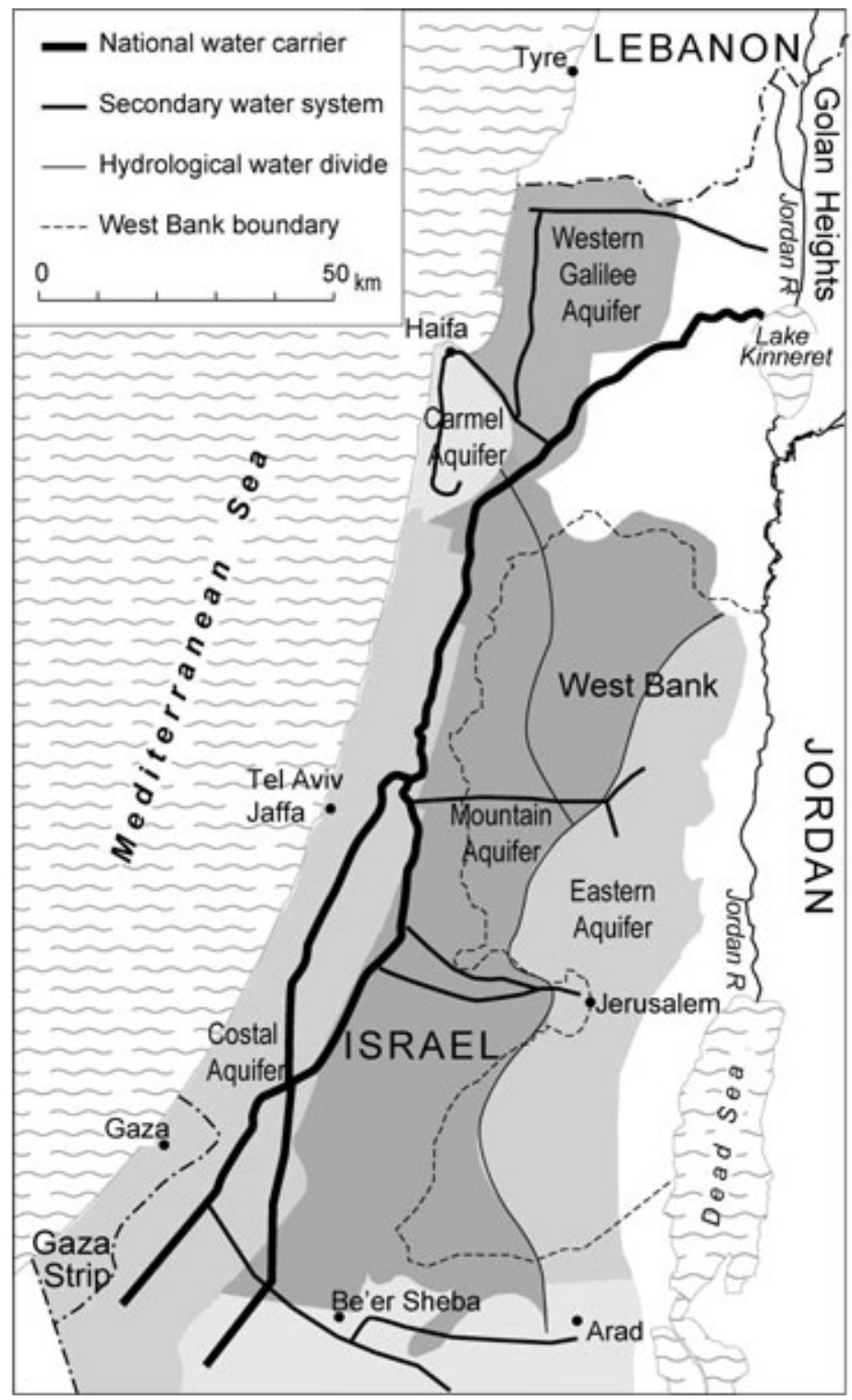

The result of these types of limitations has been an integrated system that lacks checks and balances in decision-making authority and is dominated by the agricultural sector (Fischhendler 2008). The linkage between the Israeli IWRM attributes, their overarching ideology, and the elements of IWRM that are missing are presented in Table 1.

\section{The drivers of institutional adaptation}

Despite its high degree of integration, the Israeli water system is often characterized as a system in crisis from which water is extracted beyond its replenishment rate. Because the system is interconnected, water shortages in one reservoir could be offset by a policy of overdraft in the other reservoirs. This was rationalized by the argument that overdrafts would be readdressed in subsequent 
Table 1. Water ideology, its corresponding integrated water resources management (IWRM) component, and the IWRM tools adopted for implementation.

\begin{tabular}{|c|c|c|c|}
\hline $\begin{array}{l}\text { Ideology in the } \\
\text { Israeli context }\end{array}$ & IWRM component & Tools for IWRM implementation & $\begin{array}{l}\text { Tools missing from IWRM } \\
\text { component }\end{array}$ \\
\hline $\begin{array}{l}\text { Settlement of the } \\
\text { Negev }\end{array}$ & Physical integration & $\begin{array}{l}\text { National Water Carrier } \\
\text { National Water Law } \\
\text { Conjunctive use } \\
\text { Wastewater and water integration }\end{array}$ & \\
\hline Spatial equality & $\begin{array}{l}\text { Institutional } \\
\text { integration }\end{array}$ & $\begin{array}{l}\text { Balancing Fund } \\
\text { Water quality and quantity } \\
\text { standardization } \\
\text { National Water Law } \\
\text { Water Commissioner }\end{array}$ & Economic tools \\
\hline Agrarian society & Sectoral integration & $\begin{array}{l}\text { Water Commissioner under the Ministry } \\
\text { of Agriculture } \\
\text { National Water Carrier }\end{array}$ & $\begin{array}{l}\text { Public participation } \\
\text { Proper voice for other water sectors }\end{array}$ \\
\hline Statism & $\begin{array}{l}\text { Institutional } \\
\text { integration }\end{array}$ & $\begin{array}{l}\text { National Water Carrier } \\
\text { Comprehensive legal basis } \\
\text { Centralized water institutions }\end{array}$ & $\begin{array}{l}\text { Checks and balances to counter the } \\
\text { voice of the agricultural sector }\end{array}$ \\
\hline
\end{tabular}

wet years. The result of harnessing the integration features of the system for system-wide overdrafts has been a considerable deterioration in water quality and availability in all reservoirs (Water Engineering Liquids and Irrigation 2005; Water Commission, unpublished data). This crisis has persisted since the 1980s and is attributed to the system's inability to settle the conflicting positions of the many players involved in setting and upholding water policy (IPEWA 2005a).

Although the Water Commission served as a source of sectoral and organizational integration, multiple and often competing interests took positions on water policy as water crises emerged in the late 20 th century. In part, this came from the fact that the Water Commission's authority was distributed among the eight government ministries. At the same time, within the ministries, authority over water was further fragmented across different agencies. Also, planning was carried out by Water Planning for Israel (Tahal), a government corporation, whereas the actual provision of the resource was put in the hands of a public corporation (Mekorot). As a result, at least 28 bodies maintained responsibilities over water within the framework of the Israeli IWRM system (Water Commission 2005a).

The challenge posed by the IWRM system in Israel is that it required the various ministries and water authorities to make decisions based on consensus and on building a coalition. Because the Israeli parliamentary system allows for coalitions to wield substantial political power, it would not be unusual for these coalitions to try to extract the most lucrative ministry portfolios for the sake of power, i.e., budgets. This political structure has led to both gridlock in attempts to reduce water allocation to the agricultural sector and considerable delays in efforts to build new water infrastructure (IPEWA $2005 b$ ), including desalinization plants along the Mediterranean coast (Fischhendler 2008). Many of the conflicts in this system have involved not just the decision makers and stakeholders directly involved in the Israeli water sector, but external political interests as well (Water Commission, unpublished data). This interdependency between players has impaired the system's ability to accommodate changing water demands and supply conditions (Water Commission 2005b). As a result, 
the IWRM system has often muddled along from one crisis to another with no clear vision, long-term policy, or master plan (Water Engineering Liquids and Irrigation 2005; G. Sacham, Consultant to the Water Commissioner, personal communication; IEPC2008b).

Since the 1970s, there have been many calls to reform the existing integrated system in a manner that would establish a long-term water policy guided by professional and technical expertise (Arlosoroff 1997, State Comptroller of Israel 1990, Parliamentary Commission 2002). Indeed, in 2004 a cabinet decision was made to reform the existing IWRM system. It aimed to replace the parochial interests that had dominated the IWRM system from Israel's early days (IPEWA 2005d) and accommodate emerging water supply and demand conditions (IPEWA 2005b). The proposed reform focused on establishing a new Water Authority that would concentrate all decision-making authority over water and move power out of the hands of the various ministries. The reform would effectively reduce both the number of players involved in Israeli water management as well as the number of pathways for governmental intervention in the water system.

To advance the reform, the Intergovernmental Panel for the Establishment of a Water Authority was set up with members from all relevant sectors. In all, there were 15 members on the panel representing eight different bodies, and their mandate was to reach a consensus regarding the nature of institutional adaptation required.

\section{Adaptation barriers in an integrated water resources management context}

Many of the panel's members were not supportive of reform. In particular, they demonstrated their unwillingness to transfer their responsibilities to the new Water Authority. The Ministry of Agriculture was not willing to surrender authority over drainage and water pricing (IPEWA 2005c,h). The Agricultural Ministry was particularly concerned about the potential for the new Water Authority to abolish agricultural water subsidies (IPEWA 2005c, $j$; Y. Ishi, Director of the Ministry of Agriculture, personal communication). The Interior Ministry, knowing that any reform would require the consent of all involved in the integrated system, demanded that its authority remain intact until the process of creating water "cooperations," i.e., public-private partnerships for municipal delivery and treatment, was completed (IPEWA 2005e, $i$ ). The Ministry of Environment called for all authority over water pollution to be transferred to it rather than to the proposed new body (IPEWA 2005l). The Ministry of Infrastructure was willing to support the reform as long as its minister remained in charge of the Water Authority (IPEWA 2005m). Finally, the Ministry of Finance refused to allocate a multiyear budget to the Water Authority (IPEWA 2005k), which was necessary to ensure continuity in infrastructure investments.

Not only did the panel members disagree on the redistribution of authority, but many of them also noted the risk involved in launching a new institutional structure whose implications were unknown (IPEWA 2005i). For instance, several water experts wanted to explore the option of retreating from the existing national conveyance system in which water from different sources is mixed and delivered at an equal price to all users by one operational unit. Alternatively, a regional option was suggested whereby the nation would be divided into several operational units, each providing water at a differential price and quality (Sacham, Consultant to the Water Commissioner, personal communication). The idea of disbanding the existing system and redistributing its responsibilities between new players was met with suspicion because of its implications for the reliability of water supply (M. Zida, Head of the Long-Term Planning Division of the Water Authority, personal communication). Thus, it was rejected by the Water Commission (G. Sacham, Consultant to the Water Commissioner, personal communication). Instead, the Commission worked toward a reform that would further integrate the system by concentrating power in the hands of the new Water Authority (Water Commission 2005a).

After a year of intense negotiations over the suggested reform, the intergovernmental panel reached gridlock (IPEWA 2005n). The IWRM system as represented on the panel essentially allowed every single member to hold a veto position over the rest of the panel (IPEWA 2005l). 


\section{Circumventing the barriers for adaptation}

When the intergovernmental panel reached gridlock, the Ministry of Finance proposed that the cabinet approve the reform though an omnibus bill, which required members of the Israeli parliament who supported the reform to support the entire package of legislation even if they disagreed with other portions of the bill (Oleszek 1989, Sinclair 1995). In response, the cabinet issued a decision reinforcing the need to establish a new Water Authority, despite the fact that the intergovernmental panel had not evaluated alternatives to the existing institutional water structure. The Ministry of Finance also distributed a draft of the pending Water Authority structure that included ample power for the commissioners and limited authority for the oversight committee. However, there was still a need to recruit the political support for the water reform because of the possibility of splitting this issue from the omnibus bill (Y. Ishi, Director of the Ministry of Agriculture, personal communication). This reopened the way for further negotiations over the authority's institutional structure. Indeed, the cabinet decision and the draft caused a frenzy among many of the members of the former integrated system who realized that, unless they joined the reform wagon, they would be left out of the sphere of influence.

The Ministry of Finance and the Water Commissioner, who were heavily involved in the process of recruiting the support of the various ministries, were willing to make drastic concessions. They compromised on the price of water charged to the agricultural sector, which would now be secured in a side agreement instead of by market forces (A. Levi, previous Deputy Director of the Ministry of Finance, personal communication). They also excluded control over drainage from the responsibilities of the new Water Authority. It was agreed that the responsibilities held by the Ministries of Infrastructure and the Interior would be transferred only after three years, that is, after the two ministers finished their tenure (A. Shavit, Water and Energy Officer of the Ministry of Finance, personal communication). All ministers whose authority would be diminished by the reform were to be represented on the oversight committee, and they were given discretion to choose the public representatives for that committee. It was agreed that the reform would not touch upon the institutional structure of Mekorot, thus leaving the company as the main water provider and the
National Carrier intact (A. Levi, previous Deputy Director of the Ministry of Finance, personal communication). The Ministry of Finance was willing to compromise on its direct ability to control the pricing of water but insisted that the budget for the water sector would still be determined annually, despite the need to secure long-term investments.

During the process of negotiating changes to Israel's existing IWRM institutions, key players needed to see that the benefits to reform would outweigh, or at least protect against, the political costs of the proposed changes, which in this case were defined in terms of losses in power, authority, or institutional capacity. Like most political processes, trade-offs were abundant when negotiating institutional changes. Table 2 identifies the main stakeholders involved in the reform as well as the trade-offs between the political costs they were willing to incur in accepting the reform and the benefits they received to mitigate the costs.

\section{The integrated water resources management legacy}

If we look at the nature of the Israeli water governance reform and the extensiveness of the political trade-offs made to get to that reform, it is clear that it was quite difficult both to make a fullscale change and to change quickly. Those who did receive concessions in the reform process were the usual suspects, i.e., dominant actors in the prior integration process and not new and emerging actors or claimants in the water sector. Many of these concessions were an attempt to reduce the high transaction and bargaining cost of negotiating that was imposed by the nature of the existing system.

The result was that the reform still continues to reflect the main features of the old system in several aspects: (1) representation, i.e., all of the actors who were part of the old system remain and there are no new actors as part of the process; (2) the authority structure of key stakeholders who still dominate the decision-making process; (3) the existing infrastructure, which continues to operate as a tightly coupled system; and (4) the existing operational systems, because the ability to drastically change water pricing is limited.

Although it is too early to fully analyze the effectiveness of the new system, there are 
Table 2. Political trade-offs across institutional actors affected by changes to Israel's integrated water resources management system.

\begin{tabular}{|c|c|c|}
\hline Institutional actor & Political cost incurred & Political benefits received \\
\hline Ministry of Agriculture & $\begin{array}{l}\text { Loss of ability to influence water } \\
\text { pricing }\end{array}$ & $\begin{array}{l}\text { Side agreement on water pricing } \\
\text { Input into nomination of public } \\
\text { representative on oversight committee } \\
\text { Representation on oversight committee } \\
\text { Responsibilities for drainage issues } \\
\text { unchanged }\end{array}$ \\
\hline Ministry of Interior & $\begin{array}{l}\text { Loss of authority over water pricing } \\
\text { and wastewater }\end{array}$ & $\begin{array}{l}\text { Input into nomination of public } \\
\text { representative on oversight committee } \\
\text { Gradual transfer of responsibilities } \\
\text { Representation on oversight committee }\end{array}$ \\
\hline Ministry of Infrastructure & $\begin{array}{l}\text { Loss of ministerial control over the new } \\
\text { Water Authority }\end{array}$ & $\begin{array}{l}\text { Nomination of head of Water Authority } \\
\text { Input into nomination of public } \\
\text { representative on oversight committee } \\
\text { Representation on oversight committee }\end{array}$ \\
\hline Ministry of Environment & $\begin{array}{l}\text { Loss of partial control over water } \\
\text { pollution }\end{array}$ & $\begin{array}{l}\text { Responsibilities for water quality } \\
\text { protection unchanged } \\
\text { Representation on oversight committee }\end{array}$ \\
\hline Ministry of Finance & $\begin{array}{l}\text { Conceded use of market-driven water } \\
\text { pricing } \\
\text { Conceded direct effect on water pricing }\end{array}$ & Ability to set annual water budget \\
\hline
\end{tabular}

indications that it has yet to improve water allocation and management. The new Water Authority started working in early 2007 after three years of a consecutive four-year drought with water availability of about $70 \%$ of annual average rainfall (IEPC 2008b). Despite the drought, during the last six years domestic water use has been on the rise (Intergovernmental Panel for the Establishment of a Water Authority, unpublished data). To reduce urban water consumption, the Water Authority has been trying to increase water tariffs for quantities used beyond basic water needs (IEPC 2008c). Indeed during the winter of 2007-2008, the Water Authority raised water tariffs by $15 \%$ (Water Authority 2007). Neverthless, the new tariffs were implemented only for domestic consumers and not on the agricultural sector, which consumes substantially more water (Vilan 2008). The continuation of drought during the winter of 2008 required further measures from the Water Authority. It initiated an emergency plan that included limits on water for landscaping and gardening (Water Authority 2008a) and further reductions in supply to the agricultural sector
(Water Authority 2008b). Approving further cutbacks to the agricultural sector required financial compensation for the affected farmers. The Ministry of Finance, however, did not approve any financial compensation for the winter of 2007-2008, halting further water cutbacks (T. Shor, Head of Operations at the Water Authority, personal communication).

Instead of pushing for further efficiency, the present discourse on supply problems in Israel is focused on further developing the physical network by building a western carrier that will collect water from the coastal desalination plants. At the same time, any wish to modify the existing infrastructure system to improve allocation efficiency can be blocked by the company Mekorot, which has a monopoly on the operation on the system. There is considerable criticism of Mekorot's managerial approach, which provides incentives for infrastructure expansion rather than improved efficiency (M.Zida, Head of the Long-Term Planning Division of the Water Authority, personal communication); this could possibly decouple the existing integrated system. 
The result of these impediments for sustainable water policy was that in the winter of 2007-2008, Israel faced an overdraft of 580 million $\mathrm{m}^{3}$ (Water Authority 2008c). Even if desalination continues as planned, sustainable water yields are not expected for at least a decade (Water Authority 2008c). The inability of the new Water Authority to address the crisis raised some calls to re-examine the latest water reform (IEPC 2008a) and create a new intergovernmental committee to study the continuous mismanagement of the system.

\section{DISCUSSION}

Why has the IWRM process conflicted with the ability to advance an institutional reform in Israel? As some critics of IWRM expected, challenges to institutional reform resulted from the physical, sectoral, and institutional integration of this system. In Israel, substantial investments were made in developing the storage capacity and water delivery systems needed to facilitate economic growth and agrarian expansion via an infrastructure with high sunk costs in capital, well-established sectoral beneficiaries of the system, and clearly defined institutional authority over those systems. The combination of a distribution of water management authority that is beholden to various sectoral interests with a system that guarantees high supply reliability to certain sectors meant that the transaction costs of collective action and new choices were substantial.

The system was effectively locked into the integrated structure that was originally set and later used to maintain the power hegemony of the agricultural sector. The IWRM system has led to path dependency, which, as Young (2006) found in other cases, enhances the staying power of individual arrangements and institutional structures. Thus, in designing an IWRM system it is important to be aware of the potential for that system to become what is often described as "trapped," i.e., a resilient system that does not change or adapt over time (Gunderson 1999, Gunderson and Holling 2002). This finding has profound implications for many water systems and water projects, such as the European Project NeWater, that seek to capture concurrently both integration and flexibility/ adaptation in their design (Pahl-Wostl 2007).

In considering the legacy of Israel's IWRM system, it is also important to note that it excluded some of the purported requisites essential for balanced institutional and sectoral integration. Despite sectoral integration, Israel's Zionist ideology facilitated the entrenchment of powerful agricultural interests in water policy processes. This raises the question as to whether a more inclusive IWRM system in Israel would have supported more responsiveness and adaptation. In this case, however, broader participation may not have helped. As noted, Israel's overarching governance structure fosters the need for extensive consensus and coalition building when devising policies or institutions around contested resources such as water. The difficulty in garnering the support of this coalition for a reform was, in fact, a key factor that hindered more substantive institutional reform around water resource management in Israel. When the limited reform effort did take place, it occurred only through the omnibus bill and top-down, cabinet-level pressures.

The result of an attempt to reform the water sector in an IWRM context was that it still continues to reflect the main features of the old system. Hence, not surprisingly, a new reform is already being considered just two years after the previous reform was completed. The new reform aims to be more adaptive, rather than taking the "reactive" management approach IWRM perpetuated. In Table 3, we summarize the lessons learned from the IWRM components in the Israeli case and their implications for adapting and changing water policies and practices.

\section{CONCLUSION}

Within the water governance field, IWRM has been promoted as an ideal process for addressing water management dilemmas that cross multiple sectors as well as organizational and institutional boundaries. However, little empirical attention has been paid to the challenges that IWRM may pose once implemented. The Israeli case shows that integration can come at the expense of reforming and implementing new water management policies and strategies, which are increasingly needed to deal with today's changing water supply and demand conditions. Although a few studies have seriously considered how IWRM can work in tandem with adaptive management to promote adaptability and flexibility (e.g., see Medema and Jeffrey 2005), this work has yet to consider the implications of IWRM 
Table 3. Adaptation in the context of an integrated water resources management (IWRM) system.

\begin{tabular}{lll}
\hline \hline IWRM component & $\begin{array}{l}\text { Implications for } \\
\text { institutional adaptation }\end{array}$ & $\begin{array}{l}\text { Implications for } \\
\text { water management }\end{array}$ \\
\hline Physical integration & $\begin{array}{l}\text { Increased sunk costs } \\
\text { Increased information costs }\end{array}$ & Inability to decouple the physical system \\
Sectoral integration & $\begin{array}{l}\text { Increased bargaining costs for adaptation } \\
\text { Higher number of adversarial players in } \\
\text { negotiations } \\
\text { Increased information needs }\end{array}$ & $\begin{array}{l}\text { Inability to include new players in process } \\
\text { Difficulty in reaching consensus } \\
\text { Restricted ability to change system } \\
\text { operation }\end{array}$ \\
Institutional integration & $\begin{array}{l}\text { High monitoring costs } \\
\text { Increased coordination costs }\end{array}$ & $\begin{array}{l}\text { Restricted ability to change system } \\
\text { operation }\end{array}$ \\
\hline
\end{tabular}

for establishing the new institutional arrangements needed to make water sectors truly "adaptable."

The ways in which IWRM impedes institutional change would not be a surprise to policy scholars, political scientists, and institutional theorists who have examined institutional path dependency. In many ways, the story of reform in the Israeli context fits with the standard story of path dependency, which is not uncommon in the water sector: historically benefitted interests become entrenched and are often unwilling to relinquish their control and authority (Ingram and Fraser 2006). What the analysis of the Israeli case adds is that the institutional structure of an IWRM system creates a tight coupling of these entrenched interests with the ecological system they manage. When such a social-ecological system is also placed within a context that requires consensus across many players, this tends to increase the complexity of negotiations, which in turn increases the bargaining costs for any institutional adaptation. This is in contrast to settings involving a small number of regulatory bodies and a small number of interest groups (McConnaha and Paquet 1996), which can reduce the transaction costs of decision making (Timmerman et al. 2008). In addition, the physical integration of IWRM leads to the sunk costs of largescale physical infrastructure, which further challenges any institutional reform that wishes to consider retreating from integration.

Obviously, these findings are flavored by the context of the case study setting in a system that admittedly may not fit the "ideal" model for IWRM.
Regardless of the uniqueness of the Israeli system, what seems important in any water management arena is to find ways to allow for adaptation and responsiveness to new demands while also providing long-term policy assurances that water users will have reliable and secure water supplies well into the future. Undoubtedly, some form of integrated management and planning is needed to support this latter goal. Achieving the former goal within an integrated setting appears to be the challenge. Our analysis is clearly constrained by the political lens through which we assessed this complex system of diverse water users who intersect with climate, ecology, the economy, politics, ideology, etc. Examining this system through alternate lenses will likely illuminate new and distinct challenges and solutions to sustaining water resources in this arid environment.

Responses to this article can be read online at:

http://www.ecologyandsociety.org/vol15/iss 1/art4/responses/

\section{LITERATURE CITED}

Aharoni, Y. 1991. Israel's political economy. Eshkolot, Tel Aviv, Israel.

Alatout, S. 2007. State-ing natural resources through law: the codification and articulation of water scarcity and citizenship in Israel. Arab World Geographer 10(1):16-37. 
Alatout, S. 2008. Locating the fragments of the state and their limits: water policymaking in Israel during the 1950s. Israel Studies Forum 23(1):40-65.

Arlosoroff, S. 1997. A report from the Committee for Examination of the Management of the Water Supply in Israel [title translated from the original Hebrew]. Water Commission, Jerusalem, Israel.

Asian Development Bank. 2006. Water Financing Program 2006-2010: helping to introduce IWRM in 25 river basins in the Asia-Pacific region. Available online at: http://www.adb.org/Water/WFP/ basin.asp.

Baumgartner, F. R., and B. D. Jones. 1993. Agendas and instability in American politics. University of Chicago Press, Chicago, Illinois, USA.

Biswas, A. K. 2004. Integrated water resources management: a reassessment; a water forum contribution. Water International 29(2):248-256.

Blatter, J., and H. Ingram. 2000. States, markets and beyond: governance of transboundary water resources. Natural Resources Journal 40 (2):439-471.

Blomquist, W., and E. Schlager. 2005. Political pitfalls of integrated watershed management. Society and Natural Resources 18(2):101-117.

Bressers, H., and S. Kuks, editors. 2004 Integrated governance and water basin management. Kluwer, London, UK.

Brunner, R., and T. Steelman. 2005. Beyond scientific management. Pages 1-46 in R. Brunner and T. Steelman, editors. Adaptive governance: integrating science policy and decision making. Columbia University Press, New York, New York, USA.

Dublin Statement. 1992. The Dublin Statement on Water and Sustainable Development. Available online: www.inpim.org/files/Documents/DublinStatmt. pdf.

Feitelson, E. 2005. The political economy of groundwater exploitation: the Israeli case. International Journal of Water Resources Development 21(3):413-423.
Feitelson, E., I. Fischhendler, and P. Kay. 2007. Role of a central administrator in managing water resources: the case of the Israeli water commissioner. Water Resources Research $\mathbf{4 3}$ (11):1-11.

Fischhendler, I. 2008. Institutional conditions for IWRM: the Israeli case. Ground Water 46 (1):91-102.

Galnoor, I. 1978. Water policy making in Israel. Policy Analysis 4(3):339-367.

Getches, D. H., and S. B. Van de Wettering. 2005. Integrating environmental and other public values in water allocation and management decisions. Pages 69-101 in D. S. Kenney, editor. In search of sustainable water management: international lessons for the American west and beyond. Edward Elgar, Cheltenham, UK.

Global Water Parnership (GWP). 2000. Integrated water resources management. TAC Background Paper No. 4. GWP, Stockholm, Sweden.

Global Water Partnership (GWP). 2004. Catalyzing change: a handbook for developing integrated water resource management and water efficiency strategies. GWP, Stockholm, Sweden.

Global Water Partnership (GWP). 2007. How IWRM will contribute to achieving the MDGs. Technical Committee Policy Brief No. 4. GWP, Stockholm, Sweden.

Gunderson, L. 1999. Resilience, flexibility and adaptive management: antidotes for spurious certitude. Ecology and Society 3(1): 7. [online] URL: www.consecol.org/vol3/iss1/art7/.

Gunderson, L. and C. S. Holling, editors. 2002. Panarchy: understanding transformations in human and natural systems. Island Press, Washington, D.C., USA.

Hochman, E., and O. Hochman. 1991. A policy of efficient water pricing [title translated from the original Hebrew]. Riveon Lekalkala (Economic Quarterly) 42(150):502-523.

Hoekstra, A. Y. 2006. The global dimensions of water governance: nine reasons for global arrangements in order to cope with local problems. 
Value of Water Research Report Series No. 20. UNESCO-IHE Institute for Water Education, Delft, The Netherlands.

Howe, C. W., and H. Ingram. 2005. Roles for the public and private sectors in water allocation: lessons from around the world. Pages 25-68 in D. S. Kenney, editor. In search of sustainable water management: international lessons for the American west and beyond. Edward Elgar, Cheltenham, UK.

Ingram, H., and L. Fraser. 2006. Path dependency and adroit innovation: the case of California water. Pages 78-109 in R. C. Repetto, editor. Punctuated equilibrium and the dynamics of U.S. environmental policy. Yale University Press, New Haven, Connecticut, USA.

Intergovernmental Panel for the Establishment of a Water Authority (IPEWA). 2005a. Minutes of the first meeting of the Intergovernmental Panel for the Establishment of a Water Authority, 6 January 2005 [title translated from the original Hebrew]. Water Commission, Tel Aviv, Israel.

Intergovernmental Panel for the Establishment of a Water Authority (IPEWA). 2005b. Minutes of the first meeting of the Intergovernmental Panel for the Establishment of a Water Authority, 6 January 2005 [title translated from the original Hebrew; see information provided by J. Dreysin]. Water Commission, Tel Aviv, Israel.

Intergovernmental Panel for the Establishment of a Water Authority (IPEWA). 2005c. Minutes of the first meeting of the Intergovernmental Panel for the Establishment of a Water Authority, 6 January 2005 [title translated from the original Hebrew; see information provided by Y. Ishi, Director of the Ministry of Agriculture]. Water Commission, Tel Aviv, Israel.

Intergovernmental Panel for the Establishment of a Water Authority (IPEWA). 2005d. Minutes of the first meeting of the Intergovernmental Panel for the Establishment of a Water Authority, 6 January 2005 [title translated from the original Hebrew; see information provided by S. Tal, Water Commissioner]. Water Commission, Tel Aviv, Israel.

Intergovernmental Panel for the Establishment of a Water Authority (IPEWA). 2005e. Minutes of the second meeting of the Intergovernmental Panel for the Establishment of a Water Authority, 18 January 2005 [title translated from the original Hebrew; see information provided by S. Dolberg]. Water Commission, Tel Aviv, Israel.

Intergovernmental Panel for the Establishment of a Water Authority (IPEWA). 2005f. Minutes of the second meeting of the Intergovernmental Panel for the Establishment of a Water Authority, 18 January 2005 [title translated from the original Hebrew; see information provided by J. Dreysin]. Water Commission, Tel Aviv, Israel.

Intergovernmental Panel for the Establishment of a Water Authority (IPEWA). 2005g. Minutes of the second meeting of the Intergovernmental Panel for the Establishment of a Water Authority, 18 January 2005 [title translated from the original Hebrew; see information provided by S. Tal, Water Commissioner]. Water Commission, Tel Aviv, Israel.

Intergovernmental Panel for the Establishment of a Water Authority (IPEWA). 2005h. Minutes of the seventh meeting of the Intergovernmental Panel for the Establishment of a Water Authority, 2 June 2005 [title translated from the original Hebrew]. Water Commission, Tel Aviv, Israel.

Intergovernmental Panel for the Establishment of a Water Authority (IPEWA). 2005i. Minutes of the seventh meeting of the Intergovernmental Panel for the Establishment of a Water Authority, 2 June 2005 [title translated from the original Hebrew; see information provided by M. Mordechi]. Water Commission, Tel Aviv, Israel.

Intergovernmental Panel for the Establishment of a Water Authority (IPEWA). 2005j. Minutes of the eighth meeting of the Intergovernmental Panl for the Establishment of a Water Authority, 30 June 2005. [title translated from the original Hebrew]. Water Commission, Tel Aviv, Israel.

Intergovernmental Panel for the Establishment of a Water Authority (IPEWA). 2005k. Minutes of the eighth meeting of the Intergovernmental Panl for the Establishment of a Water Authority, 30 June 2005. [title translated from the original Hebrew; see information provided by A. Shavit, Water and Energy Officer of the Ministry of Finance]. Water Commission, Tel Aviv, Israel. 
Intergovernmental Panel for the Establishment of a Water Authority (IPEWA). 2005l. Minutes of the ninth meeting of the Intergovernmental Panl for the Establishment of a Water Authority, 14 July 2005. [title translated from the original Hebrew; see information provided by S. Tal, Water Commissioner]. Water Commission, Tel Aviv, Israel.

Intergovernmental Panel for the Establishment of a Water Authority (IPEWA). 2005m. Minutes of the ninth meeting of the Intergovernmental Panl for the Establishment of a Water Authority, 14 July 2005. [title translated from the original Hebrew; see information provided by Y. Zaribi]. Water Commission, Tel Aviv, Israel.

Intergovernmental Panel for the Establishment of a Water Authority (IPEWA). 2005n. Minutes of the 11th meeting of the Intergovernmental Panel for the Establishment of a Water Authority, 3 November 2005 [title translated from the original Hebrew]. Water Commission, Tel Aviv, Israel.

Interior and Environmental Protection Committee (IEPC). 2008a. Minutes of the meeting held 18 March 2008 [title translated from the original Hebrew; see information provided by Y. Kislev]. IEPC, Tel Aviv, Israel.

Interior and Environmental Protection Committee (IEPC). 2008b. Minutes of the meeting held 18 March 2008 [title translated from the original Hebrew; see information provided by U Shani, Water Commissioner]. IEPC, Tel Aviv, Israel.

Interior and Environmental Protection Committee (IEPC). 2008c. Minutes of the meeting held 18 March 2008 [title translated from the original Hebrew; see information provided by D. Yaroslavich, Deputy Water Commissioner]. IEPC, Tel Aviv, Israel.

Jeffrey, P., and M. Geary. 2006. Integrated water resources management: lost on the road from ambition to realization? Water Sciences and Technology 53(1):1-8.

Jonker, L. 2002. Integrated water resources management: theory, practice, cases. Physics and Chemistry of the Earth 27:719-720.

Kemper, K., W. Blomquist, and A. Dinar. 2007. Integrated river basin management through decentralization. Springer, New York, New York, USA.

Kidd, S., and D. Shaw. 2007. Integrated water resource management and institutional integration: realising the potential of spatial planning in England. Geographical Journal 173(4):312-329.

Kislev, Y. 2006. The water economy of Israel. Pages 127-150 in K. D. Hambright, F. J. Ragep, and J. Ginat, editors. Water in the Middle East: cooperation and technological solutions in the Jordan Valley. University of Oklahoma Press, Norman, Oklahoma, USA.

Lee, K. 1993. Compass and gyroscope: integrating science and politics for the environment. Island Press, Washington, D.C., USA.

Levy, M. 1997. A model, a method, and a map: rational choice in comparative and historical analysis. Pages 19-41 in Mark I. Lichbach and Alan S. Zuckerman, editors. Comparative politics: rationality, culture, and structure. Cambridge University Press, Cambridge, UK.

Matondo, J. I., 2002. A comparison between conventional and integrated water resources planning and management. Physics and Chemistry of the Earth 27:831-838.

McConnaha, W. E., and P. J. Paquet. 1996. Adaptive strategies for the management of ecosystems: the Columbia River experience. American Fisheries Society Symposium 16:410-421.

Medema, W., and P. Jeffrey. 2005. IWRM and adaptive management: synergy or conflict? NeWater Report Series No. 7. Available online at: www.usf.uni-osnabrueck.de/projects/newater/downloads/ newater rs07.pdf.

Mitchell, B. 2007. Integrated catchment management and MSPs: pulling in different directions? Pages 49-67 in J. Warner, editor. Multi-stakeholder platforms for integrated water management. Ashgate, Aldershot, UK.

Molle, F., P. Wester, and P. Hirsch. 2006. River basin development and management. Chapter 17 in D. Molden, editor. Water for food, water for life: a comprehensive assessment of water management in agriculture. Earthscan, London, UK. 
Newson, M. D. 2000. Science and sustainability: addressing the world water crisis. Progress in Environmental Science,2:204-228.

North, D. C. 1990. Institutions, institutional change and economic performance. Cambridge University Press, New York, New York, USA.

Ohlson, D. W. 1999. Exploring the application of adaptive management and decision analysis to integrated watershed management. Thesis. University of British Columbia, Vancouver, British Columbia, Canada.

Oleszek, W.J. 1989. Congressional procedures and the policy process. Congressional Quarterly Press, Washington, D.C., USA.

Ostrom, E. 1990. Governing the Commons: the evolution of institutions for collective action. Cambridge University Press, New York, New York, USA.

Pahl-Wostl, C. 2007. Transitions towards adaptive management of water facing climate and global change. Water Resources Management 21 (1):49-62.

Pahl-Wostl, C., and P. Jeffrey. 2007. Adaptive water management: how to cope with uncertainty. NeWater 4(November):1-7.

Parliamentary Commission. 2002. Report of the Parliamentary Inquiry Commission on the Water Sector [title translated from the original Hebrew]. Parliamentary Commission, Jerusalem, Israel.

Pierson, P. 2000. Increasing returns, path dependence, and the study of politics. American Political Science Review 94(2):251-267 .

Roe, E., and M. Van Eeten. 2002. Reconciling ecosystem rehabilitation and service reliability mandates in large technical systems: findings and implications of three major US ecosystem management initiatives for managing humandominated aquatic-terrestrial ecosystems. Ecosystems 5(6):509-528.

Sabatier, P. A., and H. Jenkins-Smith. 1993. Policy change and learning: an advocacy coalition approach. Westview, Boulder, Colorado, USA.
Schneider, A. L., and H. Ingram. 1997. Policy design for democracy. University Press of Kansas, Lawrence, Kansas, USA.

Sinclair, B. 1995. Legislators, leaders, and lawmaking: the U.S. House of Representatives in the postreform era. Johns Hopkins University Press, Baltimore, Maryland, USA.

Sinclair, B. 1997. Unorthodox lawmaking: new legislative process in the U.S. Congress. Congressional Quarterly Press, Washington, D.C., USA.

State Comptroller of Israel. 1990. A report on the management of the water sector in Israel [title translated from the original Hebrew]. State Comptroller of Israel, Jerusalem, Israel.

Stone, D. 2002. Policy paradox: the art of political decision making. Revised edition. Norton, New York, New York, USA.

Taylor, M., and S. Singleton. 1993. The communal resource: transaction costs and the solution of collective action problems. Politics and Society 21 (2):195-214.

Teclaff, L. A. 1996. Evolution of the river basin concept in national and international water law. Natural Resources Journal 36(Spring):359-391.

Timmerman, J., J. Möltgen, and C. Pahl-Wostl. 2008. The adaptiveness of IWRM: analysing European IWRM research. IWA Publishing, London, UK.

UNEP. 2006. Human development report: beyond scarcity-power, poverty, and the global water crisis. Palgrave Macmillan for United Nations Development Program, Basingstoke, UK.

Van Cleve, F. Brie, T. Leschine, T. Klinger, and C. Simenstad. 2006. An evaluation of the influence of natural science in regional-scale restoration projects. Environmental Management 37(3):367-379.

Vilan, A. 2008. Testimony of Cabinet Member Aveshalom Vilan in front of State Comptroller Committee. In: Protocol \# 241 from State Comptroller Committee, 28.07.2008. Jerusalem, Israel. 
Water Authority. 2007. Minutes of the 13th meeting of the Water Authority, 20 December 2007 [title translated from the original Hebrew]. Water Authority, Tel Aviv, Israel.

Water Authority. 2008a. Minutes of the 16th meeting of the Water Authority, 20 February 2008 [title translated from the original Hebrew]. Water Authority, Tel Aviv, Israel.

Water Authority. 2008b. Minutes of the 19th meeting of the Water Authority, 18 May 2008 [title translated from the original Hebrew]. Water Authority, Tel Aviv, Israel.

Water Authority. 2008c. An emergency plan for the water sector [title translated from the original Hebrew]. Water Authority, Tel Aviv, Israel.

Water Commission. 2005a. Minutes of the Water Commission Internal Discussion Group Concerning the Pending Water Authority [title translated from the original Hebrew; see information provided by N. Blitz]. Water Commission, Tel Aviv, Israel.

Water Commission. 2005b. Minutes of the Water Commission Internal Discussion Group Concerning the Pending Water Authority [title translated from the original Hebrew; see information provided by J. Dreysin]. Water Commission, Tel Aviv, Israel.

Water Engineering Liquids and Irrigation. 2005. An interview with Shimon Tal, Water Commissioner [title translated from the original Hebrew]. Water Engineering Liquids and Irrigation 41:8-19.

Watson, N. 2007. Collaborative capital: a key to the successful practice of integrated water resources management. Pages 31-48 in J. Warner, editor. Multi-stakeholder platforms for integrated water management. Ashgate, Aldershot, UK.

Williamson, O. E. 1981. The economics of organization: the transaction cost approach. American Journal of Sociology 87(3):548-577.

Young, O. 2006. Vertical interplay among scaledependent environmental and resource regimes. Ecology and Society 11 (1): 27.

[online] URL: http://www.ecologyandsociety.org/vol11/ iss 1/art27/. 